\title{
The Grateful Chickadee
}

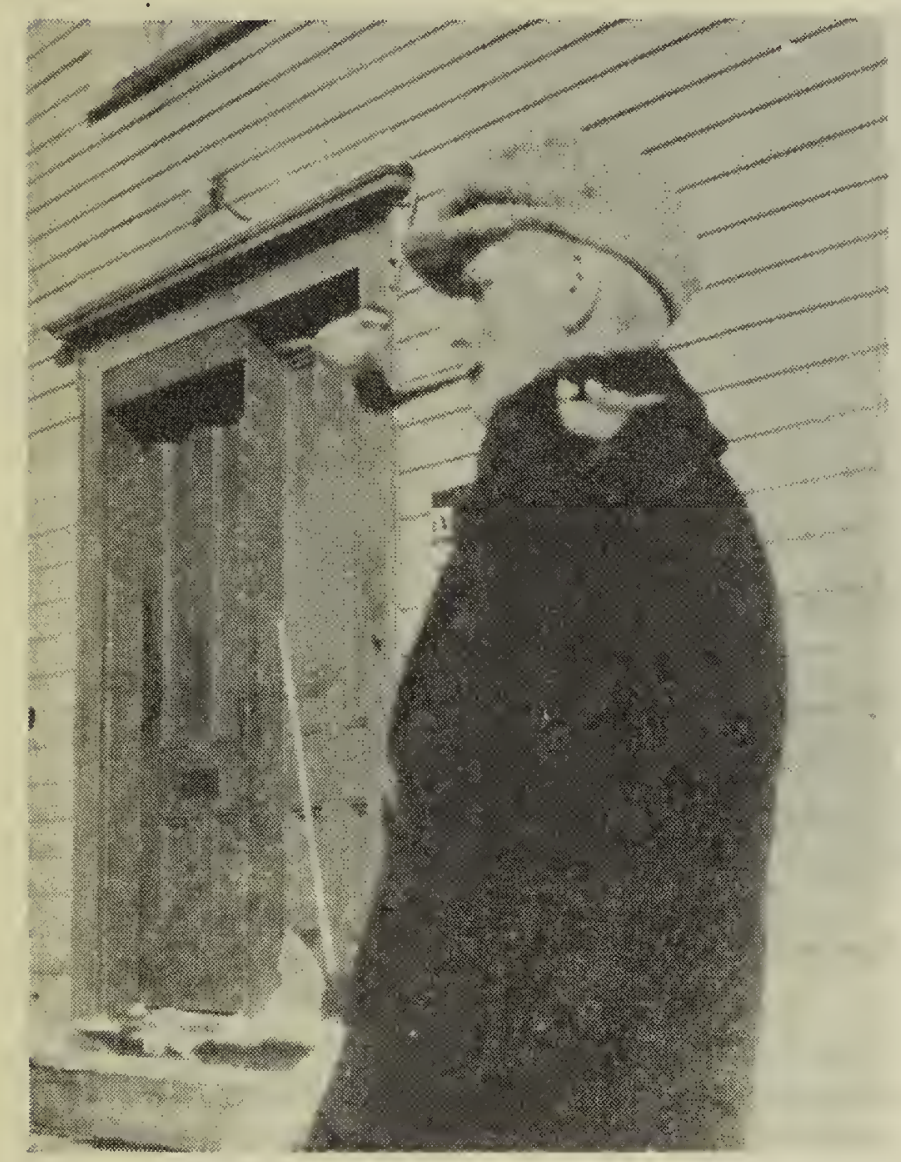

The recent deep snow brought us many friends - I mean feathered folk, but the poor Hungarian Partridges were hardest hit. Some of them starved and froze on the mountain road. The Chickadees fared better for they have been well taken care of around our door yard, with lots of bread crumbs, suet and hamburger.

I found that the clever active little fellows were easily tamed. The children in the village now get quite a kick out of feeding them. In fact if a youngster walks past our house he gets mobbed by Chickadees. The pipe in the photograph is not filled with tobacco but with hamburger. I found that they enjoyed this unusual manner of obtaining a meal. One is at it now: the other is waiting for his turn.

The following quotation from The New York Times seems very appropriate:

"No matter what other birds come to the feeding station for suet or seeds, it's the Chickadees that really repay a person for keeping a winter table set out doors. The rare visitors seldom seen in this area may make the bird-watchers eyes gleam, but little Mr. Black-Cap and his mate warm the heart. Particularly on a raw winter norning.

It's a bootless question, but one sometimes wonders about the personalities of birds, species by species. Hairy Woodpeckers seem to be illnatured gluttons. Blue Jays are pompous bullies. Nuthatches have their testy moments and seem always to expect trouble. Sparrows of almost all kinds are fluttery and somewhat quarrelsome. But the Chickadee is just a little bundle of effervescent friendship, so full of life and spirit that he pauses between bites to say a few notes of melodic thanks for being alive.

Not many birds seem to enjoy either a cold wind or a fall of snow, but the Chickadee obviously does. He seems almost to laugh when a gusty wind upsets him in mid-air, and he can frolic to his own music in a snowstorm. He actually appears to like snow more than the flitting Snowbird, which keeps busy and makes the best of snow but never actually celebrates about it.

But it is on the feeder that the Chickadee displays his innate charm at its highest. He has little fear of people. He likes an audience. He is never dour or moody, and even the squabbles with his own kind are brief. He asks little, he gives much, and he says his kind of thanks with delightful generosity. He makes the world a better place by the simple, uninhibited way he shows his own enjoyment. Mr. Chick deserves all the seeds and suet he can eat."

Three friends I see

Three tiny friends

Chickadee - dee - dee

The snow storm sends,

Here's a little suet dear

Come a little nearer

Hop on my hand, do not fear

The sky will soon be clearer

Our friends we call

Judy, June and Bill.

They warm our winter hearts

And grace our window sill.

Three little birds in a row

On. the clothes line sit

Dee-dee, we like the snow

Some suet please - a tiny bit. 